\title{
Ti-25Nb-25Ta alloy treated by plasma electrolytic oxidation in phosphoric acid for implant applications
}

\author{
Gregory Beilner ${ }^{1}$, Bruno Leandro Pereira ${ }^{1,2}$, Carlos Maurício Lepienski ${ }^{1,3}$, Gelson Biscaia de Souza ${ }^{4}$, \\ Erico Saito Szameitat ${ }^{1}$, Neide Kazue Kuromoto ${ }^{1}$, Ana Paula Rosifini Alves Claro ${ }^{5}$, \\ Viviane Seba Sampaio ${ }^{2}$, Bor Shin Chee ${ }^{2}$, Aline Rosseto da Luz ${ }^{1}$, Michael J D Nugent ${ }^{2}$
}

\footnotetext{
${ }^{1}$ LabNano, PIPE/ UFPR, Rua Francisco H dos Santos, 100 - Jardim das Américas, Curitiba, PR, Brazil.

${ }^{2}$ Materials Research Institute, AIT, Dublin Rd, Bunnavally, Athlone, Co. Westmeath, Ireland

${ }^{3}$ Department of Mechanical Engineering/ UTFPR, R. Dep. Heitor Alencar Furtado, 5000, Cidade Industrial de Curitiba, Curitiba - PR, Brazil.

${ }^{4}$ Physics Department/UEPG, Av. General Carlos Cavalcanti, 4748, Ponta Grossa, PR, Brazil.

${ }^{5}$ Department of Materials and Technology/ USP, Av. Ariberto Pereira da Cunha, 333, Guaratinguetá, SP, Brazil e-mail: beilner.gregory@gmail.com, brnlp7@gmail.com, lepiensm@ fisica.ufpr.br, gelsonbs@uepg.br, arossettoluz@gmail.com,ericoss@gmail.com,nkkuromoto@gmail.com, paula.rosifini@unesp.br, v.ssmarchi@ research.ait.ie, b.schee@research.ait.ie, MNugent@ait.ie.
}

\begin{abstract}
Among titanium alloys with non-toxic elements, the Ti-25Nb-25Ta alloy has good elastic behavior for applications in osseous implants, biocompatibility, and excellent corrosion resistance. The present study aimed to better the biocompatibility characteristics of Ti-25Nb-25Ta alloy modifying its surface through Plasma Electrolytic Oxidation (PEO) treatment. The formed oxide coating is amorphous and composed of two distinct porous formations: smaller hole-shaped pores and larger volcano-like pores. The regions with the formation of smaller pores and in the hole shaped presented the highest atomic percentage of the chemical element phosphorus. Nanoindentation tests have shown that the hardness of the Ti-25Nb-25Ta alloy is slightly lower than the commercially pure grade 2 titanium (a material used as reference), while elastic modulus measurements of Ti-25Nb-25Ta presented more suitable values for implant application (lower values when compared with titanium reference). After PEO treatment there were significant mechanical surface improvements (increased fairly surface hardness and decreased elastic modulus) for application in osseous tissue. Despite the Ti-25Nb-25Ta alloy presented excellent characteristics for applications in hard biological tissues, the PEO treatment better its features.
\end{abstract}

Keywords: Titanium alloy, Ti-25Nb-25Ta, nanoindentation, mechanical properties, Plasma Electrolytic Oxidation.

\section{INTRODUCTION}

Metallic materials used in biomedical implants are predominant in orthopedic surgical procedures and represent the main function in most orthopedic products [1]. Despite existing numerous metals and alloys produced by industry, only a small number of metallic materials can longstanding success as an implanted device [2], since they must fulfill fundamental requirements, such as high corrosion resistance, biocompatibility, and suitable mechanical properties [2-7]. Among metallic biomaterials, commercially pure titanium (cp-Ti) and Ti alloys are commonly used as dental and orthopedic devices, due to the high specific strength, low density, high corrosion resistance, and good biocompatibility [8-11]. The Ti-6Al-4V alloy was created for use in general structures and later adopted for biomedical applications [10]. However, this alloy has been questioned mainly by the toxicity of vanadium (V) and aluminum (Al) in the human body [12-14]. Although cp$\mathrm{Ti}$ and Ti-6Al-4V elastic moduli are lower when compared with Co-alloys and 316L stainless steel ones, their magnitude is still much superior concerning the cortical bone. As a result, such mismatch may induce bone reabsorption by the stress shielding effect, when implanted in body regions submitted to high and cyclical loads [15-17]. Alternatively, aiming at rule out these problems, novel alloys were proposed in which niobium $(\mathrm{Nb})$ or tantalum (Ta) substitute the toxic $\beta$-stabilizing $\mathrm{V}[10]$.

$\mathrm{Nb}$ is an excellent $\beta$-stabilizer in titanium alloys and shows great potential for osseous tissue treatments due to its reduced alloy's elastic modulus [9]. Tantalum (Ta) is well known for its high in vitro/in vivo biocompatibility $[9,18,19]$. Alloying these metals it is possible to create metallic materials with better mechani- 
cal behavior keeping the biocompatible characteristics $[9,20]$.

Ta and Nb-based $\beta$ - titanium alloys, also called the "second generation of titanium alloys", had a significant improvement when compared to $\alpha-\beta$ alloys ( Ti-6Al- $4 \mathrm{~V}$ for example) [2]. The main benefit of these materials is lower elastic modulus, increased biocompatibility, and better corrosion resistance $[2,21]$. Among various $\beta$-alloys, Ti-25Nb-25Ta alloy exhibits interesting properties like very low modulus (55 GPa), excellent corrosion resistance and superelastic behavior [22]. Despite these excellent characteristics, these materials still demand surface modifications to induce bioactivity for fast healing and improved lifespan of the prostheses.

The surface has an essential function in the reaction of the biological environment with the implant. If surface topography [23, 24], porosity [25], wettability [26, 27], chemical composition and bioactivity [28] are in suitable ranges, the osseointegration process will occur [29].

The modification of surfaces through Plasma Electrolytic Oxidations (PEO) can successfully afford the aforementioned features by controlling the experimental conditions [30-32]. This technique has been efficaciously used for the surface treatment of $\mathrm{Ta}, \mathrm{Nb}, \mathrm{Ti}$, and alloys for applications on biomaterials [33-39]. Thus, in the present paper, the Ti-25Nb-25Ta alloy was oxidized by PEO with phosphoric acid electrolyte and the experimental parameters were tailored to achieve favorable surface features for application on biomaterials area.

\section{MATERIALS AND METHODS}

\subsection{Surface preparation}

The cut and alloying process can be observed in reference [40]. The Ti-25Nb-25Ta alloy discs ( $2 \mathrm{~mm}$ thickness x $10 \mathrm{~mm} \emptyset$ ) were wet-sanded successively with P220, P320, P600, P800, and P1200 silicon carbide grinding paper. After that, the specimens were cleaned for 15 minutes in propanone, ethanol, and distilled water sequentially in an ultrasonic bath. Finally, the discs were then left in the incubator for 24 hours at $40^{\circ} \mathrm{C}$. $\mathrm{Cp}$-Ti samples were prepared using the same protocol for comparison purposes.

\subsection{Plasma electrolytic oxidation (PEO) conditions}

Treatments were performed in an electrolytic cell using 1 mol. $\mathrm{L}^{-1} \mathrm{H}_{3} \mathrm{PO}_{4}$ electrolyte under constant $300 \mathrm{~V}$ (potentiostatic mode) provided by a Chroma 62024P-80-60 DC power supply during 60 seconds. The oxidation was carried out at room temperature, with constant stirring, and using a titanium bar as counter-electrode.

\subsection{Morphology and structural characterization}

For the microstructure characterization, the specimens were initially polished with $9 \mu \mathrm{m}$ diamond suspension and colloidal silica. Then, ternary alloy disks were etched for 10 minutes in a solution composed by $3 \mathrm{~mL}$ of $\mathrm{HF}, 6 \mathrm{~mL}$ of $\mathrm{HNO}_{3}$, and $91 \mathrm{~mL}$ of deionized water (Kroll solution, see reference [41]). Subsequently, the etched surface images were obtained by optical microscopy (Zeiss microscope).

Cross-sectioned specimens were analyzed by scanning electronic microscopy (SEM) (Tescan Vega 3 LMU). Crystalline phases were characterized by X-ray diffraction (XRD) in the $20^{\circ} \leq 2 \theta \leq 85^{\circ}$ range and scan speed $1 \%$ minute, in the Bragg-Brentano geometry with $\mathrm{Cu} \mathrm{K \alpha}$ radiation $(\lambda=1.54 \AA)$. It was applied 15 $\mathrm{kV}$ in the energy-dispersive X-ray spectroscopy (EDS) equipment to find the surface chemical composition. The measurements were done in three distinct ways: mapping mode for visualizing the elemental concentration; pointing mode to quantify the atomic percentage in distinct morphologies; and line mode at the crosssectional regions. For cross-sectional observations, specimens were mounted into a plastic resin and then mechanically cut. After, the plastic resin was removed with immersion in propanone for $24 \mathrm{~h}$. Only for the cross-section SEM observations, the specimens were covered with gold.

\subsection{Hardness and Elastic Modulus}

Elastic modulus $E$ and hardness $(H)$ were measured by instrumented indentation technique using a UNAT Nanoindenter (Zwick-Roell/Asmec), employing the Quasi-Continuous Stiffness Method (QCSM) and a Berkovich diamond tip. The maximum force was $500 \mathrm{mN}$. A sampling of 35 indentations was obtained on each surface. 


\section{RESULTS AND DISCUSSION}

Fig. 1 shows the polished Ti-25Nb-25Ta alloy image obtained by an optical microscope after etched in Kroll solution for 10 minutes. The size of the grains was in the range of tens to hundreds of micrometers, while the shapes of the grains do not exhibit a preferential orientation. Furthermore, this result is similar to reported by Bertrand and co-workers for an alike Ti-25Nb-25Ta alloy [22].

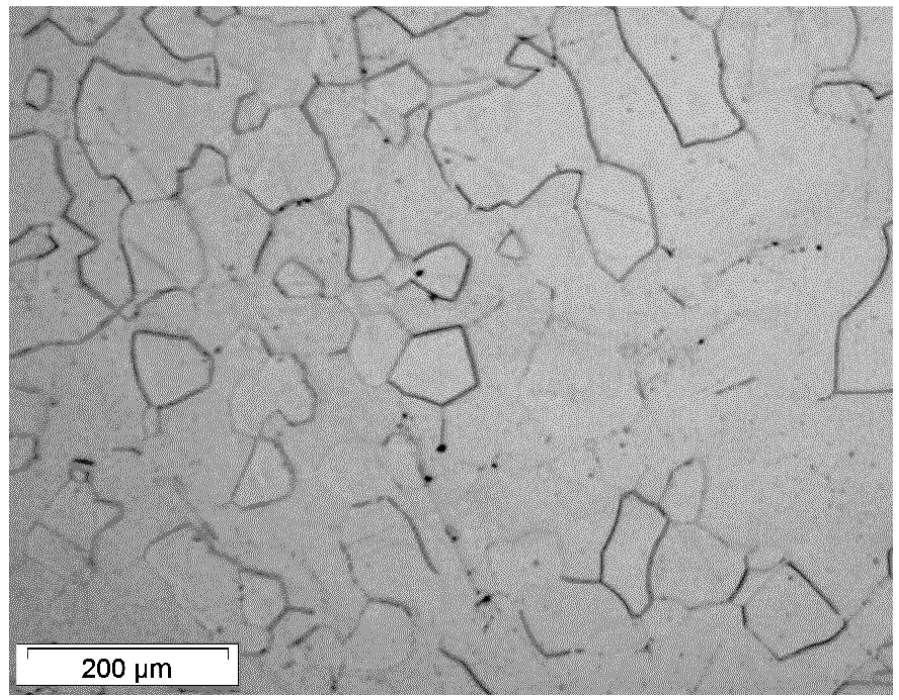

Fig. 1. Optical micrograph of the Ti-25Nb-25Ta microstructure obtained after immersion in Kroll solution.

Fig. 2 shows the X-ray diffractograms of the oxidized Ti-25Nb-25Ta alloy and the reference surface only polished. Both conditions disclosed the $\beta$-phase and $\alpha$ "-metastable phase peaks. The $\beta$ phase is a result of the $\mathrm{Nb}$ and $\mathrm{Ta}$ elements in the Ti-25Nb-25Ta system, which play a role as $\beta$ stabilizers [42]. The $\alpha$ " is a metastable phase with an orthorhombic crystal system, corresponding a stage between the Hexagonal Closed Packed (hcp) and the Body Cubic Center (bcc) [43-45]. In the XRD pattern of the Ti-25Nb-25Ta, the hogback is related to the natural oxide that forms spontaneously over the alloy exposed to environments containing oxygen. Typically, is observed that the PEO treatment produces crystalline oxides on $\mathrm{Ti}, \mathrm{Nb}, \mathrm{Ta}$, and their alloys [30, 46-48]. The PEO micro-discharges causes local intense pressures and high temperatures, presenting a high degree of temperature variation. The temperature gradient reaches levels able to melt the oxide being sequentially rapidly cooled by contact with the electrolyte, which can induce crystallinity in the forming oxides [49]. Despite the occurrence of micro-discharges, there is no signal of crystalline oxide formation. There are no peaks ascribed to the oxide layer produced by PEO. The "hogback" in the $17^{\circ}-30^{\circ}$ range corresponds to amorphous oxides. When the PEO treatments were carried out in phosphoric acid solution using constant voltage on $\mathrm{Nb}$ (under $350 \mathrm{~V}$ ) and $\mathrm{Ti}$ ( under $200 \mathrm{~V}$ ) there is a formation of an amorphous oxide or a poorly crystalline oxide [46, 50-52]. In anodic films (the stage before the coating formed by micro-discharges) were observed the crystalline oxide formed most easily at the metal/oxide than the oxide growth at the oxide/electrolyte interface. It was attributed to the incorporation of ion impurity from the electrolyte [53]. Similarly, metals with a high concentration of alloying elements when were fast cooled from the melting point presented remained amorphous structures whereas the pure metals only crystalline[53]. Zhu also verified a negative influence of the phosphorus quantities on the degree of crystallinity after performed PEO using electrolytes containing Ca and P [54]. Summarizing, the PEO process using phosphoric acid under $300 \mathrm{~V}$ produced an amorphous oxide layer. 


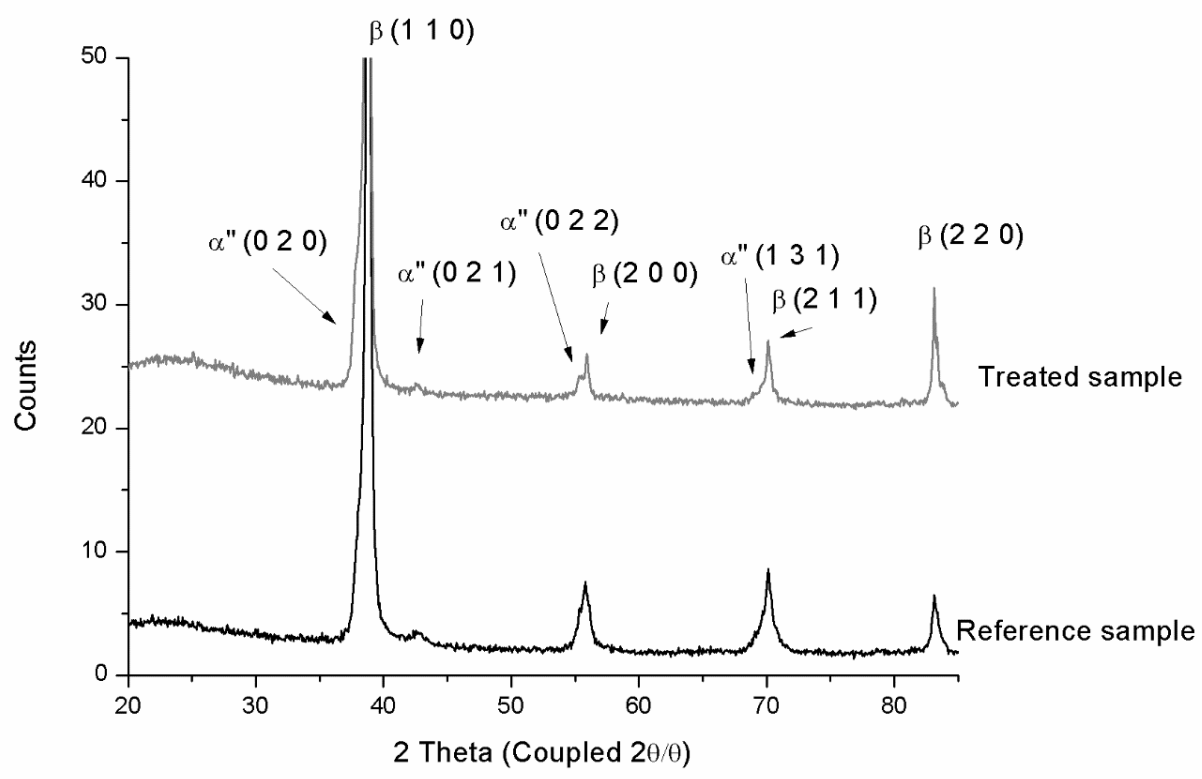

Fig. 2: XRD patterns of Ti-25Nb-25Ta alloy surface treated by the PEO process (grey line) and polished surface (black line).

Fig. 3 shows the surface morphology after treatment by Plasma Electrolytic Oxidation of the Ti-25Nb25Ta alloy. The coating presented no visible cracks at the selected resolution. A porous formation can be observed over the entire surface, presenting two distinct morphologies. Areas with the smallest and flat-like pores (hole formation) are similar to the morphology observed in pure titanium treated by PEO using the same electrolyte [55]. Areas with the largest and prominent pores (volcano formation) are comparable with those produced on niobium PEO treated with phosphoric acid plus hydrogen peroxide [46]. Differently from titanium, in the niobium oxidation process, there is a previous formation before the volcano formation. This formation was described as a compact oxide surface covered with semi-spheroids distributed over the flat surface [39]. The discharge channels occur mainly onto the semi-spheroids due to the geometry, which has a more intense local electric field [46]. These events increase the local temperature melting the oxide. The melted oxide is removed from the discharge channel by forces and rapidly cooled when getting contact with the electrolyte [56] given the volcano shape [46]. Thus, the formation of the pores showed characteristics from niobium and titanium treated by PEO in the phosphoric electrolyte. The pores formed in this work were in the nano and micrometrical range. Porous surfaces increase the implant contact area with the human tissues and accelerate the healing process [57]. Besides, open pores are an important feature because the living tissue may grow into the cavities [58] providing better mechanical stability. Moreover, it was reported that the apatite growth initiates firstly inside the pore structures [59]. 

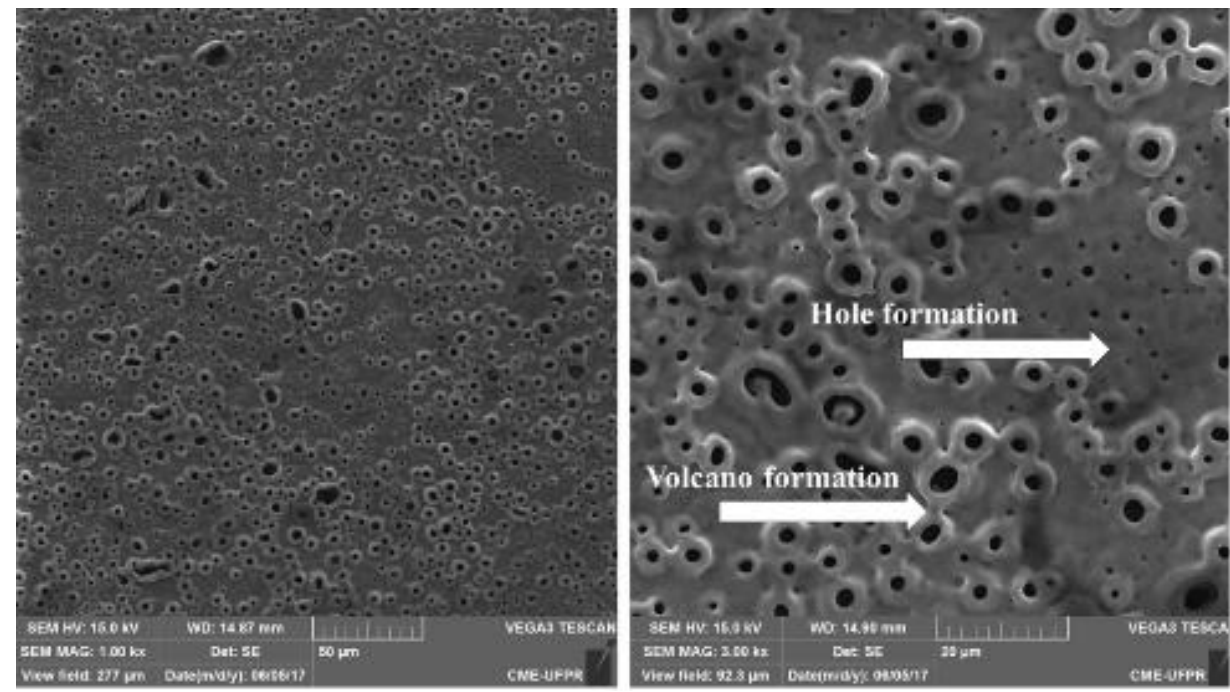

Fig. 3: SEM images at two magnifications ( $1 \mathrm{kX}$ - right side and $3 \mathrm{kX}$ - left side) of the Ti-25Nb-25Ta alloy oxidized in 1 mol. $1^{-1} \mathrm{H}_{3} \mathrm{PO}_{4}$ under $300 \mathrm{~V}$ for $60 \mathrm{~s}$.

Fig. 4 shows the chemical surface distribution of $\mathrm{P}, \mathrm{O}, \mathrm{Ti}, \mathrm{Nb}$, and Ta obtained by EDS in mapping mode. Just as a rough estimate, the depth range probed by EDS inside Ti-25Nb-25Ta was calculated from the Kanaya-Okayama equation [60] as being about $0.8 \mu \mathrm{m}$ for $\mathrm{Ti}$ and $1.0 \mu \mathrm{m}$ for $\mathrm{P}$ and $\mathrm{O}$. This restrained the electron volume of interaction entirely inside the PEO coating, as seen further during the SEM-EDS crosssection analyses, with virtually no interference of the substrate. The data displays the presence of substrate elements $(\mathrm{Ti}, \mathrm{Nb}$, and $\mathrm{Ta}$ ) in the coating and $\mathrm{P}$ and $\mathrm{O}$ incorporated from the electrolyte. Most of the elements displayed an overall uniform distribution in the analyzed area. Phosphorus presented an evident contrast between areas with predominant large and small pores. Comparatively, regions with the smallest pores disclosed higher phosphorus concentrations. Three EDS point analyses were performed over the area with the smallest pores (points 1, 2, and 3), and the other 3 points over the biggest pores' regions (points 4, 5, and 6). Table 1 presents the average atomic percentage for each distinct region. The element $\mathrm{P}$ is normally found in coatings formed in phosphoric acid and there is a positive relation between phosphate content and hydrophilicity[39, 46, 61]. Similarly in the cellular membrane, which is composed of a phospholipid bilayer, the phosphate group is responsible for the hydrophilicity of the membrane outer side [62]. The reason is that phosphate presents polar characteristics [62] and polar surfaces frequently exhibit high hydrophilic behavior [63]. For implant applications where the osseointegration is desired, hydrophilic surfaces allow better interaction with blood tissue, improve the cell adhesion and spread [64]. 


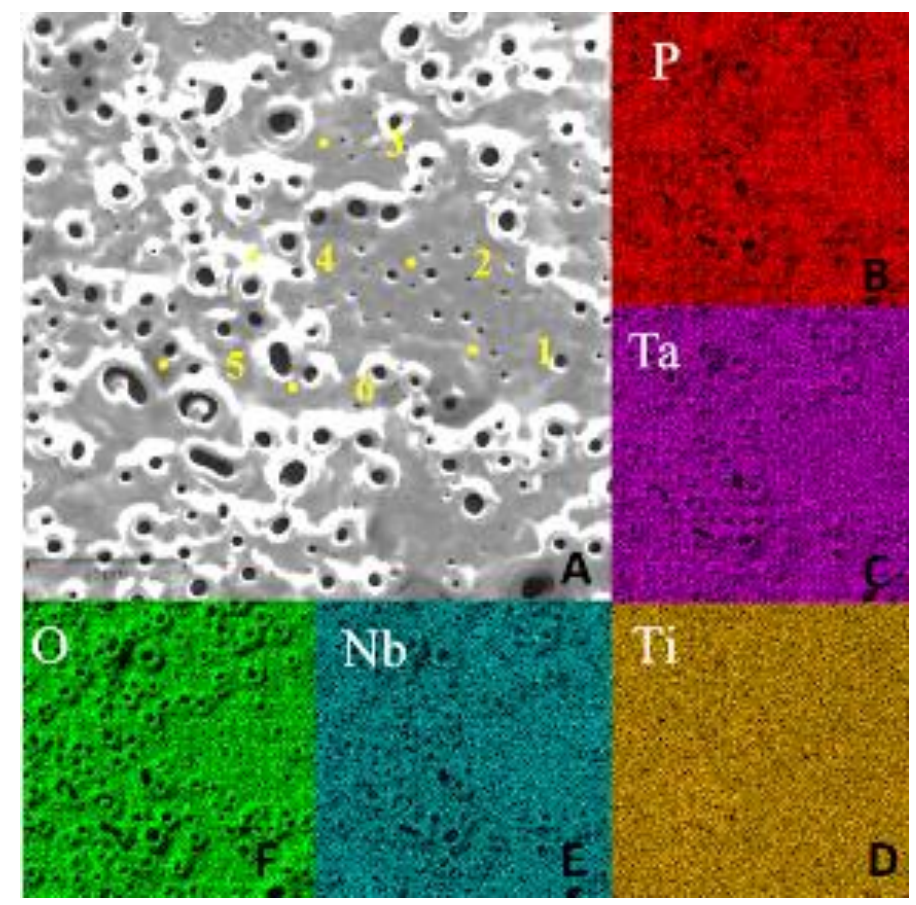

Fig. 4: (a) SEM image of the Ti-25Nb-25Ta region treated by the PEO process and after analyzed by EDS in mapping mode, as shown in the panels (b)-(f). The points 1-6 marked in (a) correspond to point EDS analysis (see Table 1).

The elements percentage of distinct morphologies are different. Comparing the region of the smallest pores with the region of the biggest pores it is possible to observe that the phosphorus percentage decreased by $41 \%$, titanium and tantalum decreased by $22 \%$, niobium by $9 \%$, and oxygen increased by $11 \%$. The region with the biggest pores had more intense discharges during the PEO process, probably due to lower electrical resistance during the oxidation process. The EDS results and SEM images suggest an inverse relationship between the discharge intensity (electrical conductivity) and $\mathrm{PO}_{4}^{-3}$ incorporation.

Table 1: The average atomic percentage of the region with small pores (points 1,2, and 3) and that region with larger pores (points 4, 5, and 6) shown in Fig. 4, measured through EDS point analysis.

\begin{tabular}{l|c|c}
\hline ELEMENT & $\begin{array}{c}\text { ATOMIC PERCENTAGE AVERAGE OF POINTS } \\
\mathbf{1 , 2 , \text { AND 3 }}\end{array}$ & $\begin{array}{c}\text { ATOMIC PERCENTAGE AVERAGE OF } \\
\text { POINTS 4, 5, AND 6 }\end{array}$ \\
\hline Oxygen & $68.6 \pm 0.7$ & $76.8 \pm 0.6$ \\
\hline Phosphorus & $9.1 \pm 0.4$ & $5.4 \pm 0.5$ \\
\hline Titanium & $16.3 \pm 0.6$ & $12.7 \pm 0.1$ \\
\hline Niobium & $3.3 \pm 0.3$ & $3.00 \pm 0.03$ \\
\hline Tantalum & $2.7 \pm 0.2$ & $2.1 \pm 0.7$ \\
\hline
\end{tabular}

Cross-sectional analyses of two different regions on the PEO-treated material are presented in Fig 5. The specimen was positioned at a low angle with the sectional plane that allowed observing the specimen in a high depth of field. Under this perspective, the oxide layer presents a rugged morphology that is very rough, rounded and the coating thickness is $(7 \pm 2) \mu \mathrm{m}$. The EDS line scan (Fig. 5.c) was performed across the yellow line which begins on the layer top, crossing the coating and entering the metallic substrate. The vertical dash line represents the visual coating/substrate limit, while the profiles correspond to atomic percentages along the yellow line length. At the visually identified interface, the phosphorus and oxygen atomic concentrations decreased while $\mathrm{Ti}, \mathrm{Ta}$, and $\mathrm{Nb}$ percentages increased, confirming a transition between oxide and substrate. However, the transition between the oxide and the coating was gradual, presenting approximately 3 $\mu \mathrm{m}$. This phenomenon can be explained by two effects: migration of ions at the interface, and because of the micrometer-sized volume of interaction produced by the incident electron beam within the bulk. 


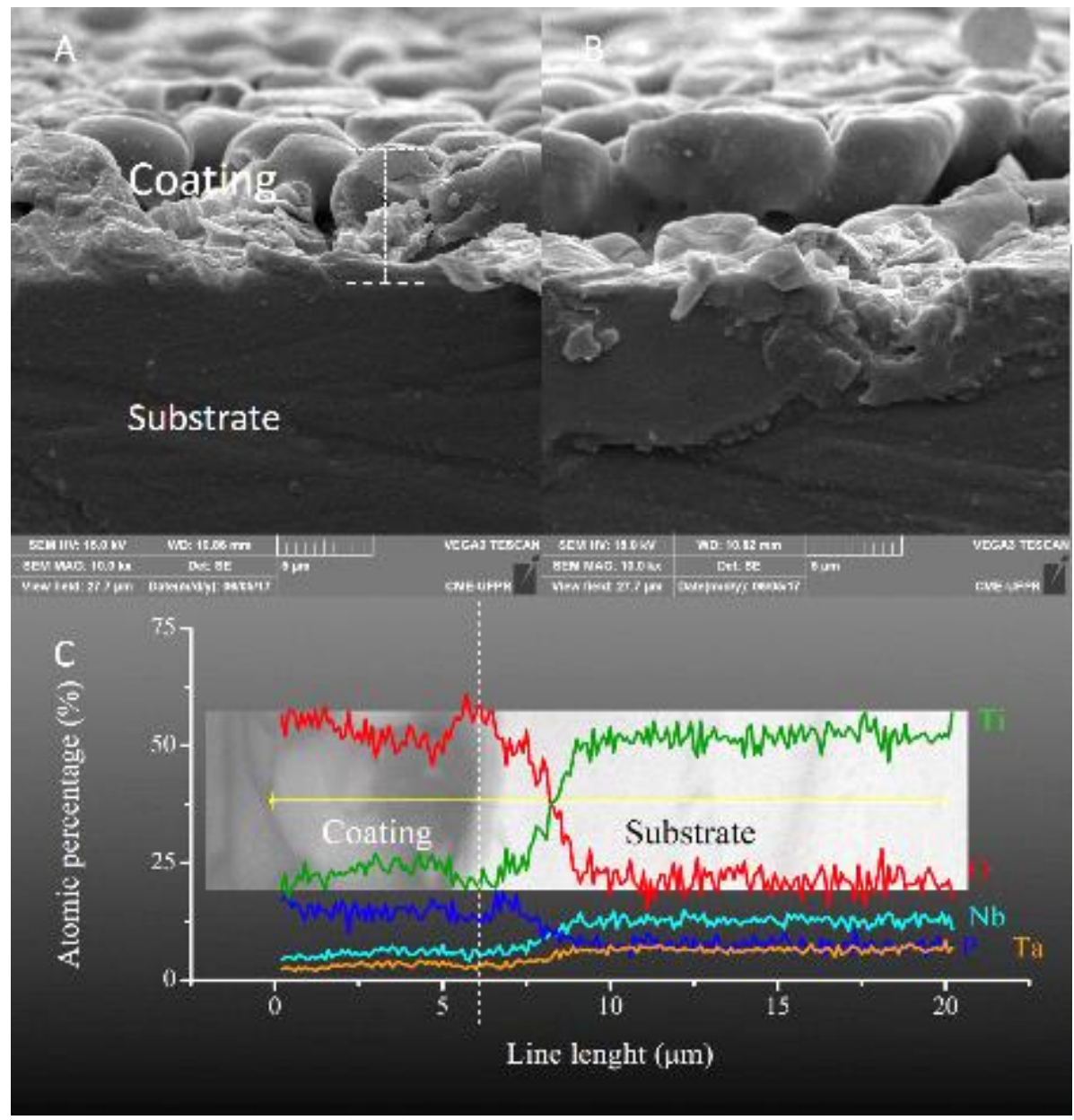

Fig. 5: : (a) and (b) SEM images of two distinct cross-section regions obtained on the oxidized Ti-25Nb25Ta. (c) EDS line scan performed across the yellow straight line, starting at the very top surface of the PEO coating and entering the metallic substrate.

Elastic modulus $(E)$ and Hardness $(H)$ measurements of the oxidized surface and the polished alloy substrate are shown in Fig. 6, along with profiles of the polished commercially pure titanium surface. The comparison is worthwhile since $\alpha$-Ti is largely used in the biomaterials area. Both $H$ and $E$ profiles of the Ti$25 \mathrm{Nb}-25 \mathrm{Ta}$ alloy were lower than those of the titanium. The addition of $\beta$-phase stabilizer elements improved mechanical properties of the alloy for implant use by lowering $E$.

Profiles obtained on the PEO-treated surface presented a larger dispersion than the polished surfaces, this is a result of the indenter interaction with asperities and pores. Such irregularities cause errors during the tip-surface contact, while the porosity affects the plastic deformation field $[65,66]$. The maximum depths reached in the instrumented indentation tests were in the $\sim 3.5 \mu \mathrm{m}$ of profundity. Despite this, the influence zone of applied normal forces may surpass the coating thickness, depending on their magnitude. Another point is that PEO coatings are composed of different layers with distinct porosity [46], which certainly will have also different mechanical responses. Hence, hardness and elastic modulus profiles of Fig 6 correspond to a combination of coating and substrate responses [67]. The hardness of the coating plus substrate system was $5.8 \mathrm{GPa}$ at shallow depths, a value 2.3 times superior to the polished Ti-25Nb-25Ta alloy (2.5 GPa) and twice as higher than the polished Ti reference $(\sim 3 \mathrm{GPa})$. Into higher penetration depths, the hardness profile converged to the substrate value $(1.9 \mathrm{GPa})$.

The E profile of the coating plus substrate system was, on average, lower than the metallic alloy substrate $(\sim 70 \mathrm{GPa})$ and the polished $\mathrm{Ti}(\sim 125 \mathrm{GPa})$. This result can partially be attributed to the layer porosity since the weighted fraction of pores contributes to the composite elastic modulus [68]. To sum up, the PEO with phosphoric acid improved, even more, the elastic modulus and hardness of the Ti-25Nb-25Ta surface for orthopedic implant applications. Higher hardness and elastic modulus near to the bone values are associated with the enhanced coating integrity, as well as to the bone mechanical acceptability. An elevated hardness is a property closely related to reducing wear, which is an important matter for considering in the relative motion and debris release at the implant site [69]. Alternatively, an artificial bone implant exposed to 
cyclical high loads may develop a biological negative phenomenon known as bone reabsorption, which is especially severe when elastic moduli of bone and implant differ significantly [7]. In that situation, the mechanical load is distributed in a non-uniform manner in the bone/implant interface. The osseous tissue will lack enough mechanical load solicitation, while the implant will carry most of the load. Over time, the bone environment will react losing osseous mass around the bone/implant interface [7], compromising the mechanical stability and the implant lifetime. Although bone resorption is a phenomenon related to the bulk prosthesis, it must also be a concern in the design of bioactive layers, since load transference between living tissue and the artificial implant is critical at interfaces. Possibly, an elastic modulus gradient from the cortical bone $(10-30 \mathrm{GPa})[3]$ to the coating $(\sim 60 \mathrm{GPa})$ and then to the substrate $(\sim 70 \mathrm{GPa})$ can be more favorable than an abrupt change to avoid the layer's fracture and detachment under micromotions, which take place at the implant site. Such effect, however, must be analyzed comprehensively and is beyond the scope of this study.
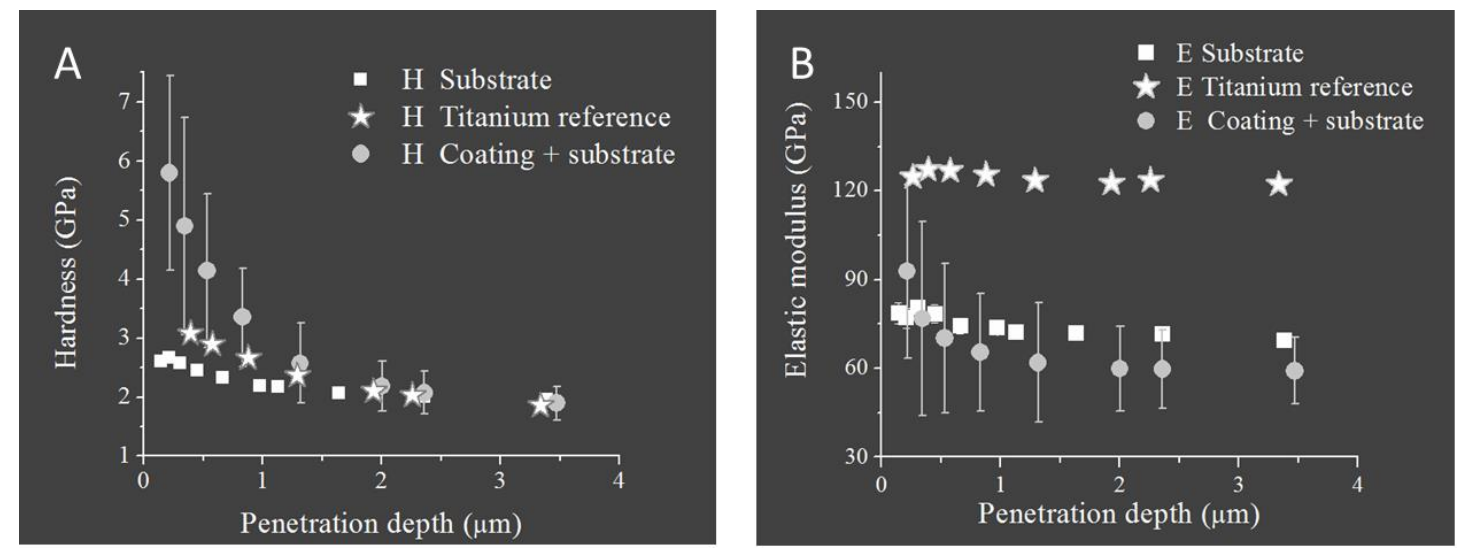

Fig. 6: (a) Hardness and (b) elastic modulus as a penetration depth function of the polished Ti-25Nb-25Ta alloy (substrate), titanium reference, and the treated Ti-25Nb-25Ta alloy surface by PEO (Coating + substrate).

\section{CONCLUSIONS}

The Ti-25Nb-25Ta alloy surface was treated by Plasma Electrolytic Oxidation with phosphoric acid. The treatment produced a porous coating with two types (volcano and hole formation) of a non-crystalline oxide formation. Regions with small pores presented higher phosphorus concentration than those with larger and volcano-like pores. The surface hardness of Ti-25Nb-25Ta had a significant improvement after PEO treatment. Likewise, the elastic modulus improved after treatment, reducing in comparison with the metallic substrate and providing an elastic gradient for the bone-implant interface. Moreover, both substrate and coating disclosed more suitable mechanical properties values for use in bone implants than titanium commercially pure grade 2. Despite the Ti-25Nb-25Ta alloy presented excellent characteristics for applications in osseous tissue, the PEO treatment better its features.

\section{ACKNOWLEDGMENTS}

The authors thank Fundação Araucária, GOI (Government of Ireland), and CAPES (Coordenação de Aperfeiçoamento de Pessoal de Nível Superior) for financial support; C-LABMU at State University of Ponta Grossa (UEPG), LabNano (laboratório de propriedades nanomecânicas), LORXI (Laboratório de Óptica de Raios-X e Instrumentacão), CME (centro de microscopia eletrônica) at Federal University of Paraná (UFPR).

\section{AUTHOR CONTRIBUTIONS}

Authors: Bruno Leandro Pereira: Conceptualization, Formal analysis, Methodology, Writing - Original Draft, Writing - Review \& Editing, Investigation; Gregory Beilner: Conceptualization, Formal analysis, Methodology, Writing - Original Draft, Investigation; Carlos Maurício Lepienski: Conceptualization, Methodology, Project administration, Supervision, Writing - Review \& Editing, Formal analysis; Gelson Biscaia de Souza: Conceptualization, Methodology, Writing - Review \& Editing, Investigation, Formal analysis; Erico Saito Szameitat: Formal analysis, Investigation, Methodology; Bor Shin Chee: Writing - 
Review \& Editing, Investigation; Neide Kazue Kuromoto: Conceptualization, Methodology, Formal analysis, Resources, Writing - Review \& Editing; Viviane Seba Sampaio: Writing - Review \& Editing, Investigation; Aline Rosseto da Luz: Writing - Original Draft; Ana Paula Rosifini Alves Claro: Resources, and Michael J D Nugent: Conceptualization, Methodology, Resources, Supervision, Writing - Review \& Editing.

\section{REFERENCES}

[1] MAZZOCCA, A.D., CAPUTO, A.E., MAST, J.W.M.M. "Principles of Internal Fixation. In: Browner BD, editor. Principles of internal fixation Skeletal trauma: basic science, management and reconstruction". Philadelphia; p. 195-249, 2008.

[2] CHEN, Q., THOUAS, G.A. "Metallic implant biomaterials". Mater Sci Eng R Reports. v. 87, p. 1-57, 2015.

[3] NIINOMI M. "Mechanical biocompatibilities of titanium alloys for biomedical applications". J Mech Behav Biomed Mater. v. 1, n. 1, p. 30-42, 2008.

[4] JACKSON, MJ. "Review : titanium and titanium alloy applications in medicine" Matej Balazic and Januz Kopac Waqar Ahmed. v. 1, p.3-34, 2007

[5] GILBERT, J.L., KUBACKI G.W. "Oxidative Stress, Inflammation, and the Corrosion of Metallic Biomaterials. In: Oxidative Stress and Biomaterials". Elsevier; p. 59-88, 2016

[6] GROSS, S., ABEL, E. "A finite element analysis of hollow stemmed hip prostheses as a means of reducing stress shielding of the femur". J Biomech. 2001 v. 34, n. 8, p. 995-1003, 2001.

[7] JOSHI, M.G., ADVANI, S.G., MILLER F., et al. "Analysis of a femoral hip prosthesis designed to reduce stress shielding". J Biomech. v. 33, n. 12, p. 1655-1662, 2000.

[8] FAZEL, M., SALIMIJAZI, H.R., GOLOZAR, M.A., et al. "A comparison of corrosion, tribocorrosion and electrochemical impedance properties of pure $\mathrm{Ti}$ and $\mathrm{Ti6Al4V}$ alloy treated by micro-arc oxidation process". Appl Surf Sci. v. 324, p. 751-756, 2015.

[9] LIU, J., CHANG, L., LIU, H., et al." Microstructure, mechanical behavior and biocompatibility of powder metallurgy Nb-Ti-Ta alloys as biomedical material ". Mater Sci Eng C. v. 71, p. 512-519, 2017.

[10] NIINOMI, M. "Recent metallic materials for biomedical applications". Metall Mater Trans A. v. 33, n. 3, p. 477-486, 2002.

[11] CIMENOGLU, H., GUNYUZ, M., KOSE, G.T., et al. "Micro-arc oxidation of Ti6Al4V and Ti6Al7Nb alloys for biomedical applications." Mater Charact v. 62, n. 3, p. 304-311, 2011.

[12] RHOADS, L.S., SILKWORTH, W.T., ROPPOLO, M.L., et al. "Cytotoxicity of nanostructured vanadium oxide on human cells in vitro". Toxicol Vitr v. 24, n. 1, p. 292-296, 2010.

[13] RESS, N.B., CHOU, B.J., RENNE, R.A., et al. Carcinogenicity of Inhaled Vanadium Pentoxide in F344/N Rats and B6C3F1 Mice. Toxicol Sci v. 74, n. 2, p. 287-296, 2003.

[14] DARBRE, P.D. "Environmental oestrogens, cosmetics and breast cancer". Best Pract Res Clin Endocrinol Metab v. 20, n. 1, p. 121-143, 2006

[15] LONG, M., RACK, H.J. "Titanium alloys in total joint replacement--a materials science perspective". Biomaterials. v. 19, n. 18, p. 1621-1639, 1998.

[16] DA SILVA, L.M., CLARO, A., BUZALAF, M.A.R., et al. "Influence of the Substitutional Solute on the Mechanical Properties of Ti-Nb Binary Alloys for Biomedical Use." Mater Res J Mater. v. 15, n. 3, p. 355$358,2012$.

[17] MOHAMMED, M.T., KHAN, Z.A., SIDDIQUEE, A.N. "Beta titanium alloys: the lowest-elastic modulus for biomedical applications: a review." Int J Chem. v. 8, n. 8, p. 822-827, 2014.

[18] BALLA, V.K., BODHAK, S., BOSE, S., et al. "Porous tantalum structures for bone implants: Fabrication, mechanical and in vitro biological properties." Acta Biomater v. 6, n. 8, p. 3349-3359, 2010.

[19] WANG, H., LI, J., YANG, H., et al. "Fabrication, characterization and in vitro biocompatibility evaluation of porous $\mathrm{Ta}-\mathrm{Nb}$ alloy for bone tissue engineering." Mater Sci Eng C v. 40, p. 71-75, 2014.

[20] CIMPEAN, A., MITRAN, V., CIOFRANGEANU, C.M., et al." Osteoblast cell behavior on the new beta-type Ti - 25Ta-25Nb alloy." Mater Sci Eng C v. 5, n. 1, p. 74-132, 2017.

[21] DAVIS, J.R. "Handbook of Materials for Medical Devices". ASM International; 2003.

[22] BERTRAND, E., GLORIANT, T., GORDIN, D.M., et al. "Synthesis and characterisation of a new 
superelastic Ti-25Ta-25Nb biomedical alloy." J Mech Behav Biomed Mater. v. 3, n. 8, p. 559-564, 2010.

[23] GUPTA, S., DAHIYA, V., SHUKLA, P. "Surface topography of dental implants: A review." J Dent Implant v. 4, n. 1, p. 66, 2014.

[24] ANSELME, K. "Osteoblast adhesion on biomaterials". Biomaterials v. 21, n. 7, p. 667-681, 2000.

[25] KUBOKI, Y., TAKITA, H., KOBAYASHI, D., et al. "BMP-induced osteogenesis on the surface of hydroxyapatite with geometrically feasible and nonfeasible structures: topology of osteogenesis." J Biomed Mater Res v. 39, n. 2, p. 190-9, 1998.

[26] BACAKOVA, L., FILOVA, E., PARIZEK, M., et al. "Modulation of cell adhesion, proliferation and differentiation on materials designed for body implants." Biotechnol Adv v. 29, n. 6, p. 739-67, 2011.

[27] PARK, J.H., WASILEWSKI,C.E., ALMODOVAR, N., et al. "The responses to surface wettability gradients induced by chitosan nanofilms on microtextured titanium mediated by specific integrin receptors." Biomaterials v. 33, n. 30, p. 7386-93, 2012.

[28] YAN, W.Q., NAKAMURA, T., KOBAYASHI, et al. "Bonding of chemically treated titanium implants to bone." J Biomed Mater Res v. 37, n. 2, p. 267-75, 1997.

[29] KOKUBO, T., TAKADAMA, H. "How useful is SBF in predicting in vivo bone bioactivity?" Biomaterials v. 27, n. 15, p. 2907-15, 2006.

[30] SOWA, M., WOSZCZAK, M., KAZEK-KĘSIK, et al. "Influence of process parameters on plasma electrolytic surface treatment of tantalum for biomedical applications." Appl Surf Sci. v. 407, p. 52-63, 2017.

[31] DARBAND, G.B., ALIOFKHAZRAEI, M., HAMGHALAM, et al. "Plasma electrolytic oxidation of magnesium and its alloys: Mechanism, properties and applications." J Magnes Alloy v. 5, n. 1, p. 74-132, 2017.

[32] YANG Z., WU Y. K.. ZHANG X. Z., et al. "An interesting anodic oxidation behavior of plasma electrolytic oxidation coatings fabricated on aluminum in alkaline phosphate electrolyte", Surfaces and Interfaces. V. 16, p. 199-205, 2019.

[33] PEREIRA, B.L., TUMMLER, P., MARINO, C.E.B., et al. "Titanium bioactivity surfaces obtained by chemical/electrochemical treatments". Rev. Matéria, v. 19, n. 1, p. 16-23, 2014.

[34] YEROKHIN, A., PARFENOV, E.V., MATTHEWS, A. "In situ impedance spectroscopy of the plasma electrolytic oxidation process for deposition of Ca- and P-containing coatings on Ti". Surface and Coatings Technology. V.301, p.54-62, 2016.

[35] LUGOVSKOY, A., ZINIGR, M.” Plasma Electrolytic Oxidation of Valve Metals”. In: Materials Science - Advanced Topics, 1 ed., chapter 4, InTech, 2013.

[36] YEROKHIN, A. L, NIE, X., LEYLAND, et al." Plasma electrolysis for surface engineering". Surf Coatings Technol v. 122, n. 2-3, p. 73-93, 1999.

[37] LUKIYANCHUK, I.V., RUDNEV, V.S., TYRINA, L.M., et al. "Plasma electrolytic oxide coatings on valve metals and their activity in CO oxidation." Applied Surface Science v. 315, p. 481-489, 2014

[38] VASILI, R., ZEKOVI, L. "Characterization of oxide coatings formed on tantalum by plasma electrolytic oxidation in 12-tungstosilicic acid". Applied Surface Science v. 257, p. 10590-10594, 2011.

[39] PEREIRA, B.L., LEPIENSKI, C.M., MAZZARO, I., et al. "Apatite grown in niobium by two-step plasma electrolytic oxidation". Material and Science Engineering C. v. 77, p. 1235-1241, 2017.

[40] PEREIRA, B.L., Beilner, G., Lepienski, C.M., et al. "Oxide coating containing apatite formed on Ti$25 \mathrm{Nb}-25 \mathrm{Ta}$ alloy treated by Two-Step Plasma Electrolytic Oxidation". Surface \& Coatings Technology v. 382, 2020.

[41] MUTLU, I. "Synthesis and characterization of Ti - Co alloy foam for biomedical applications". Trans Nonferrous Met Soc China. v. 26, n. 1, p. 126-137, 2016.

[42] SEIXAS, M.R., BORTOLINI, C., KONATU, R.T., et al. "Mechanical and Microstructural Characterization of the Ti-25Ta-25Nb Alloy for Dental Applications". Materials Characterization v. 869, p. 935-939, 2016.

[43] XU, L. Metastable beta titanium alloys: tuning their beta phase stability and low-temperature martensitic transformation. M.Sc. Thesis, Delft University of Technology, Delft, Netherlands, 2015.

[44] SATTURWAR, P.M., FULZELE, S. V., DORLE, A.K. "Biodegradation and in vivo biocompatibility of rosin: a natural film-forming polymer". AAPS PharmSciTech. v. 4, n. 4, p. 434-439, 2004.

[45] VULCAN, A.D., RADUCANU, D., COJOCARU, V.D., et al. "X-ray diffraction of a ti-ta-nb alloy 
processed". UPB Sci Bull, v.74, Ser B. 2012

[46] PEREIRA, B.L, DA LUZ, A.R., LEPIENSKI, C.M., et al. "Niobium treated by Plasma Electrolytic Oxidation with calcium and phosphorus electrolytes." J Mech Behav Biomed Mater, v. 77, p. 347-352, 2018.

[47] GEBERT, A., EIGEL, D., GOSTIN, P.F., et al., "Oxidation treatments of beta-type Ti-40Nb for biomedical use", Surf. Coatings Technol., v. 302, p. 88-99, 2016.

[48] NABAVI, H.F., ALIOFKHAZRAEI, M., ROUHAGHDAM A.S, "Electrical characteristics and discharge properties of hybrid plasma electrolytic oxidation on titanium", Journal of Alloys and Compounds, v.728, p. 464-475, 2017.

[49] FATTAH-AlHOSSEINI, A., BABAEI, K., MOLAEI, M., "Plasma electrolytic oxidation (PEO) treatment of zinc and its alloys: A review”, Surfaces and Interfaces, v.18, 2020.

[50] CHEN, Z.X, TAKAO, Y., WANG, W.X, et al. "Surface characteristics and in vitro biocompatibility of titanium anodized in a phosphoric acid solution at different voltages"., Biomed. Mater. V.4, 2009

[51] TÜMMLER, P., PEREIRA B.L., LEPIENSKI, C.M, et. al, "Bioactive films on titanium surface obtained by anodic oxidation in sulphuric and phosphoric acid", In: 21st Brazilian Congress of Mechanical Engineering, p. 2007-2012, 2011.

[52] JAEGGI, C., PARLINSKA-WOJTAN, M., KERN, P., "Correlation of electrolyte-derived inclusions to crystallization in the early stage of anodic oxide film growth on titanium", Thin Solid Films., v. 520, p. 18041808, 2012.

[53] LEACH, J.S.L., PEARSON, B.R., "Crystallization in anodic oxide films”, Corros. Sci., v. 28 p. 43-56, 1988.

[54] ZHU, X., KIM, K.H., JEONG, Y., “Anodic oxide films containing Ca and P of titanium biomaterial”, Biomaterials, v. 22, p. 2199-2206, 2001.

[55] SOARES, P., MIKOWSKI, A. "Hardness and elastic modulus of TiO2 anodic films measured by instrumented indentation." J Biomed Mater Res B Appl Biomater. v. 84, n. 2, p. 524-530, 2008.

[56] DURDU, S., AYTAC, A., USTA, M. "Characterization and corrosion behavior of ceramic coating on magnesium by micro-arc oxidation". Journal of Alloys and Compounds v. 509, p. 8601-8606, 2011.

[57] HULBERT, S.F., MORRISON, S.J., KLAWITTER, J.J., "Tissue reaction to three ceramics of porous and non-porous structures", J. Biomed. Mater. Res., v. 6, p. 347-374, 1972.

[58] ANDANI, M.T., SHAYESTEH MOGHADDAM, N., et al. "Metals for bone implants. Part 1. Powder metallurgy and implant rendering." Acta Biomater., v. 10, p. 4058-4070, 2014.

[59] RAO, X., CHU, C.L., SUN, Q., et al. "Fabrication and apatite inducing ability of different porous titania structures by PEO treatment." Mater Sci Eng C, v. 66, p. 297-305, 2017.

[60] GEISS, R.H. Energy-dispersive X-ray spectroscopy. Encycl. Mater. Charact. Boston: ButterworthHeinemann;. 120-134 p. 1992

[61] BEILNER, G., Tratamento superficial na liga ti-25nb-25ta para implantes biomédicos, M.Sc. Thesis, Federal University of Parana, Paraná, Curitiba, 2018.

[62] SINGER S., NICOLSON, G.L.," The fluid mosaic model of the structure of cell membranes" Science, v.175, p.720-731, 1972.

[63] M. KANDUČ, E. SCHNECK, R.R. NETZ, "Attraction between hydrated hydrophilic surfaces", Chem. Phys. Lett., v. 610-611, p. 375-380, 2014.

[64] A. TOFFOLI, L. PARISI, M.G. BIANCHI, et al. "Thermal treatment to increase titanium wettability induces selective proteins adsorption from blood serum thus affecting osteoblasts adhesion”, Mater. Sci. Eng. C, v. 107, 2020.

[65] LIMA, G.G. DE, SOUZA, G.B. DE, LEPIENSKI, C.M., et al. "Mechanical properties of anodic titanium films containing ions of $\mathrm{Ca}$ and $\mathrm{P}$ submitted to heat and hydrothermal treatment." J Mech Behav Biomed Mater., v. 64, p. 18-30, 2016.

[66] DE SOUZA, G.B., MIKOWSKI, A., LEPIENSKI, C.M., et al. "Indentation hardness of rough surfaces produced by plasma-based ion implantation processes." Surf Coatings Technol v. 204, n. 18-19, p. 30133017,2010

[67] SAHA, R., NIX, W.D. "Effects of the substrate on the determination of thin film mechanical properties by nanoindentation." Acta Mater. v. 50, p. 23-38, 2002.

[68] MEYERS, M., CHAWLA, K. Mechanical behavior of materials. 2009 
[69] KORKUSUZ, P., KORKUSUZ, F. "Hard Tissue - Biomaterial Interactions." Biomaterials in Orthopedics, Marcel Dekker, 2004.

\section{ORCID}

Gregory Beilner

Bruno Leandro Pereira

Carlos Maurício Lepienski

Erico Saito Szameitat

Bor Shin Chee

Neide Kazue Kuromoto

Michael J D Nugent

Ana Paula Rosifini Alves Claro

Gelson Biscaia de Souza

Viviane Seba Sampaio

Aline Rosseto da Luz https://orcid.org/0000-0002-9409-2326

https://orcid.org/0000-0002-7039-168X

https://orcid.org/0000-0002-9759-9704

https://orcid.org/0000-0003-2732-1683

https://orcid.org/0000-0003-1606-1759

https://orcid.org/0000-0001-8032-5523

https://orcid.org/0000-0002-7469-4389

https://orcid.org/0000-0003-3353-4247

https://orcid.org/0000-0003-2347-1609

https://orcid.org/0000-0003-4266-0675

https://orcid.org/0000-0002-0652-8901 